\title{
The Nonpeptide Calcitonin Gene-Related Peptide Receptor Antagonist BIBN4096BS Lowers the Activity of Neurons with Meningeal Input in the Rat Spinal Trigeminal Nucleus
}

\author{
Michael Jochen Marco Fischer, Stanislav Koulchitsky, and Karl Messlinger \\ Institute of Physiology and Experimental Pathophysiology, University of Erlangen-Nürnberg, D-91054 Erlangen, Germany
}

\begin{abstract}
Calcitonin gene-related peptide (CGRP) has been suggested to play a major role in the pathogenesis of migraines and other primary headaches. CGRP may be involved in the control of neuronal activity in the spinal trigeminal nucleus (STN), which integrates nociceptive afferent inputs from trigeminal tissues, including intracranial afferents. The activity of STN neurons is thought to reflect the activity of central trigeminal nociceptive pathways causing facial pain and headaches in humans.

In a rat model of meningeal nociception, single neuronal activity in the STN was recorded. All units had receptive fields located in the exposed parietal dura mater. Heat and cold stimuli were repetitively applied to the dura in a fixed pattern of ramps and steps. The nonpeptide CGRP receptor antagonist BIBN4096BS was topically applied onto the exposed dura or infused intravenously.

BIBN4096BS (300 $\mu \mathrm{g} / \mathrm{kg}$, i.v.) reduced spontaneous activity by $\sim 30 \%$, the additional dose of $900 \mu \mathrm{g} / \mathrm{kg}$ intravenously by $\sim 50 \%$ of the initial activity, whereas saline had no effect. The activity evoked by heat ramps was also reduced after BIBN4096BS (900 $\mu \mathrm{g} / \mathrm{kg}$, i.v.) by $\sim 50 \%$. Topical administration of BIBN4096BS (1 mM) did not significantly change the spontaneous neuronal activity within $15 \mathrm{~min}$.

We conclude that the endogenous release of CGRP significantly contributes to the maintenance of spontaneous activity in STN neurons. Blockade of CGRP receptors, possibly at central and peripheral sites, may therefore be an effective way to decrease nociceptive transmission. This may offer a new therapeutic strategy for the treatment of facial pain and primary headaches.
\end{abstract}

Key words: migraine; headache; meningeal nociception; olcegepant; pain; neuropeptide; CGRP

\section{Introduction}

Neuropeptide release is an important effector mechanism associated with nociceptor stimulation. The neuropeptide calcitonin gene-related peptide (CGRP) is found in a subset of polymodal nociceptive afferents that are activated by a variety of noxious stimuli, including heat (Caterina et al., 1999, 2000; Davis et al., 2000). CGRP release from these afferents in the dorsal horn enhances thermal and mechanical nociceptive sensitivity (Bennett et al., 2000; Sun et al., 2003). In peripheral tissues, CGRP released from perivascular afferents contributes to the development and maintenance of neurogenic inflammation (Brain and Williams, 1985; Brain et al., 1985; Gamse and Saria, 1986). Meningeal (dural and pial) blood vessels are innervated by a dense network of trigeminal sensory fibers, a major proportion of which contains CGRP (Edvinsson et al., 1987; Keller and Marfurt, 1991; Messlinger et al., 1993). CGRP is released on stimulation from both the peripheral and central processes of these trigeminal af-

Received March 4, 2005; revised April 21, 2005; accepted May 13, 2005.

This work was supported by the Bundesministerium für Bildung und Forschung (German Headache Consortium). S.K. was a Fellow of the Alexander Von Humboldt Foundation. We thank J. Schramm, M. Schulte, and B. Vogler for their technical assistance and Dr. R. Carr for reading this manuscript.

Correspondence should be addressed to Dr. Karl Messlinger, Institute of Physiology and Experimental Pathophysiology, University of Erlangen-Nürnberg, Universitätstrasse 17, D-91054 Erlangen, Germany. E-mail: messlinger@physiologie1.uni-erlangen.de.

D0I:10.1523/JNEUROSCI.0869-05.2005

Copyright $\odot 2005$ Society for Neuroscience $\quad$ 0270-6474/05/255877-07\$15.00/0 ferents (Messlinger et al., 1995; Jenkins et al., 2004). Importantly, CGRP concentrations are raised in the jugular venous blood during stimulation of the trigeminal ganglion in animals (Goadsby and Edvinsson, 1993) and in humans during migraine attacks, cluster headaches, and chronic tension-type headaches (Goadsby et al., 1990; Goadsby and Edvinsson, 1994a; Ashina et al., 2000). Additionally, infusion of CGRP in migraineurs can trigger a migraine attack (Lassen et al., 2002). Together, CGRP seems to play an important role in nociceptive processing in the trigeminovascular system, which underlies the generation of headaches.

The significance of CGRP is substantiated by the main effects of the antimigraine drug family of triptans. Sumatriptan has long been shown to reduce CGRP release concomitant with the relief of migraine pain and other primary headaches (Goadsby and Edvinsson, 1993). Triptans inhibit CGRP release by activating serotonin $5-\mathrm{HT}_{1 \mathrm{D}}$ receptors located on trigeminal afferents, and they constrict meningeal arterial vessels by activating vascular $5-\mathrm{HT}_{1 \mathrm{~B}}$ receptors (Hargreaves and Shepheard, 1999). These effects are not exclusive for the trigeminovascular system but include, in particular, the coronary circulation. The Triptan Cardiovascular Safety Expert Panel (Dodick et al., 2004) recommended their use in the absence of cardiac contraindications. Therefore, the development of CGRP receptor antagonists seemed to be an alternative perspective for antimigraine therapy. Recently, BIBN4096BS, the first nonpeptide CGRP receptor antagonist (Doods et al., 2000), has been tested successfully in the 
treatment of acute migraine (Olesen et al., 2004). In parallel, in an animal preparation of meningeal nociception, BIBN4096BS has been shown recently to reduce the activity of central trigeminal neurons evoked by glutamate microiontophoresis or by electrical stimulation of the superior sagittal sinus (Storer et al., 2004).

The purpose of this study was to investigate the effects of BIBN4096BS on the spontaneous and heat-evoked activity in the spinal trigeminal nucleus (STN). An animal preparation of meningeal nociception with repetitive thermal test stimuli was used as a model for the trigeminal mechanisms in headache pathophysiology.

\section{Materials and Methods}

The experiments were performed in accordance with the ethical issues of the International Association for the Study of Pain (Zimmermann, 1983). The experimental protocol was reviewed by an ethics committee and approved by the local district government.

Experimental procedures. Male Wistar rats with body weights ranging from 300 to $480 \mathrm{~g}$ were used. Details of the surgical and recording procedures have been described previously (Schepelmann et al., 1999; Koulchitsky et al., 2004). Briefly, rats were anesthetized with an initial intraperitoneal dose of $120-150 \mathrm{mg} / \mathrm{kg}$ thiopentone (Trapanal; Byk Gulden, Konstanz, Germany). The femoral artery was cannulated to monitor arterial blood pressure, and the femoral vein was cannulated for the administration of drugs. The animals were tracheotomized, paralyzed with intravenous administration of gallamine triethiodide $(40 \mathrm{mg} / \mathrm{kg})$, and artificially ventilated with oxygen-enriched room air. Expiratory $\mathrm{CO}_{2}$ was monitored and maintained at $4.5-5 \%$. Body temperature was maintained at $37-37.5^{\circ} \mathrm{C}$ with a feedback-controlled homoeothermic system (TKM 0902; Föhr Medical Instruments, Frankfurt, Germany). The animals were kept under deep anesthesia throughout the experiment with supplementary doses of thiopental given as required to suppress nociceptive reflexes or blood pressure changes evoked by noxious pinch stimuli of the earlobes. Vital parameters (blood pressure, heart rate, expiratory $\mathrm{CO}_{2}$ level, and body temperature) were continuously recorded throughout the experiment. The experiments were terminated with a lethal intravenous dose of thiopentone.

Head surgery and electrophysiological recordings. The animals were placed in a stereotaxic frame with the head held in a fixed position by ear bars. The skin overlying the skull was opened, and the cranium was exposed. Using a drill and fine forceps, a cranial window of $\sim 6 \mathrm{~mm}$ (rostrocaudal) and $\sim 4 \mathrm{~mm}$ (inferior-superior) was carefully cut into the left parietal bone to expose the dura mater. During surgery and throughout the experiment, the dura was protected from drying with isotonic saline. The neck muscles were divided along the animal's midline, and the medullary brainstem was exposed by cutting a window through the atlanto-occipital ligament and the underlying dura mater. Carbon fiber glass microelectrodes (impedance, 1-6 M $\Omega$ ) were inserted and advanced into the ipsilateral medulla in $2.5 \mu \mathrm{m}$ steps using a microstepper. Singleshock stimuli ( $0.5 \mathrm{~ms}$ pulses; $10-12 \mathrm{~V} ; 0.2 \mathrm{~Hz})$ were delivered to the exposed dura through bipolar electrodes with their rounded tips touching the dural surface. Neurons in the subnucleus caudalis of the STN with input from meningeal afferents were identified by their regular discharges in response to electrical stimulation and by their responses to mechanical probing of the dura. The position and size of dural receptive fields were determined with von Frey filaments $(0.05-10 \mathrm{mN})$, and facial receptive fields indicating convergent afferent input were located with a fine, blunt glass rod. The extracellular signals were bandpassed, amplified, and digitized with a sampling rate of $20 \mathrm{kHz}$ before being recorded to disk using SPIKE software (Forster and Handwerker, 1990). The position of the electrode for each recording site was determined by measuring the distance caudal and lateral to the obex and by reading the depth of the microdrive.

Experimental protocols. Throughout the experiment, the number of impulses was counted and displayed. The spontaneous activity of all units was recorded for a control period of $\geq 30 \mathrm{~min}$ before application of substances. BIBN4096BS was topically applied to the exposed dura at 1 $\mathrm{mM}$ and observed for $15 \mathrm{~min}$ before optional intravenous application. BIBN4096BS was diluted in saline and slowly injected (300 $\mu \mathrm{g} / \mathrm{kg}$, i.v.) over a period of $5 \mathrm{~min}$. After $26 \mathrm{~min}$ of observation, an additional dose of $900 \mu \mathrm{g} / \mathrm{kg}$, resulting in a cumulative dose of $1200 \mu \mathrm{g} / \mathrm{kg}$, was injected. In another series of experiments, lidocaine (2\%) was topically applied to the dura after the control period.

Using a feedback-controlled vortex device (Beise et al., 1998) with a flat circular thermode, $4 \mathrm{~mm}$ in diameter, the surface temperature of the dura was kept at $32^{\circ} \mathrm{C}$. Thermal stimulation before and after every drug administration included two heat stimulation protocols and one cold stimulation protocol. The first heat stimulus consisted of a ramp with a slope of $0.1^{\circ} \mathrm{C} / \mathrm{s}$ from 32 to $44^{\circ} \mathrm{C}$, at which the temperature was held for $30 \mathrm{~s}$ and then returned to $32^{\circ} \mathrm{C}$ over $4 \mathrm{~s}$. The second heat stimulus protocol was applied $180 \mathrm{~s}$ after the first and consisted of $4^{\circ} \mathrm{C}$ temperature steps to 36,40 , and $44^{\circ} \mathrm{C}$, each sequentially reached over $2 \mathrm{~s}$ and held for $30 \mathrm{~s}$ before the temperature returned to a baseline of $32^{\circ} \mathrm{C}$ over $4 \mathrm{~s}$. In the third protocol applied $180 \mathrm{~s}$ after the second, the temperature was decreased by $6^{\circ} \mathrm{C}$ over $2 \mathrm{~s}$ to 26 and $20^{\circ} \mathrm{C}$, held for $30 \mathrm{~s}$ at each temperature, and then returned to baseline.

Substances. BIBN4096BS was provided by Boehringer-Ingelheim (Mannheim, Germany) (Doods et al., 2000). Topical and intravenous solutions were made in saline with $0.2 \% \mathrm{HCl}$ and titrated to a pH level of $4.5-5$ with $\mathrm{NaOH}$. Xylocaine was purchased from AstraZeneca (Wedel, Germany).

Data analysis. Repeated measurements of experimental groups were compared using Wilcoxon matched-pairs tests, and differences between experimental groups were analyzed using a Mann-Whitney $U$ test. All tests were performed with Statistica software (StatSoft, Tulsa, OK). All values are given as mean \pm SEM unless otherwise noted. Differences were considered significant at $p<0.05$ and are marked by asterisks in the figures.

\section{Results}

\section{General properties of units}

From 31 male Wistar rats $(368 \pm 8 \mathrm{~g})$, a total of 36 neurons with meningeal receptive fields recorded in the left caudal subnucleus of the STN were included. The recording sites were located 1.23/ $2.13 / 3.13 \mathrm{~mm}$ (minimum/mean/maximum) caudal to the obex, $1.10 / 1.73 / 2.50 \mathrm{~mm}$ lateral from the midline, and at a depth of $0.08 / 0.83 / 1.42 \mathrm{~mm}$ from the dorsal surface of the medulla. The recording coordinates read from the microdrives have been confirmed previously with electrolytic lesions (Koulchitsky et al., 2004). At the electrical threshold, the minimal response latency to dural electrical stimulation was $11.7 \pm 0.8 \mathrm{~ms}$. Dural receptive fields were usually spot-like and located at, or close to, branches of the medial meningeal artery. Von Frey thresholds within dural receptive fields were $0.9 \pm 0.3 \mathrm{mN}$. All units also had lowthreshold facial receptive fields predominantly in the ophthalmic region, as has been found in previous studies (Schepelmann et al., 1999). Increasing the pressure stimuli into the noxious range or pinching the facial receptive fields with sharp forceps caused considerable increases in neuronal activity, revealing the wide dynamic range character of all units. The rate of mean spontaneous activity was within the range of $0.06-24.4$ impulses/s, and the mean rate was 4.8 ( $\pm 1.0 \mathrm{SEM})$ impulses per second.

\section{Effects of BIBN4096BS on spontaneous activity}

After a control period of $30 \mathrm{~min}$, BIBN4096BS ( $1 \mathrm{~mm} ; 50 \mu \mathrm{l}$ ) was topically applied to the exposed dura mater. The spontaneous firing rate did not change within the 15 min period after application (Fig. 1a). In another set of experiments, topical application of the local anesthetic xylocaine $(2 \% ; 50 \mu \mathrm{l})$ to the dura reduced spontaneous activity, which was significant from the fourth minute after administration of xylocaine (Fig. $1 b)(p<0.05$; Wilcoxon),

Intravenous injection of BIBN4096BS $(300 \mu \mathrm{g} / \mathrm{kg})$ caused a $28 \%$ reduction of discharge frequency ( $5 \mathrm{~min}$ period before vs 5 

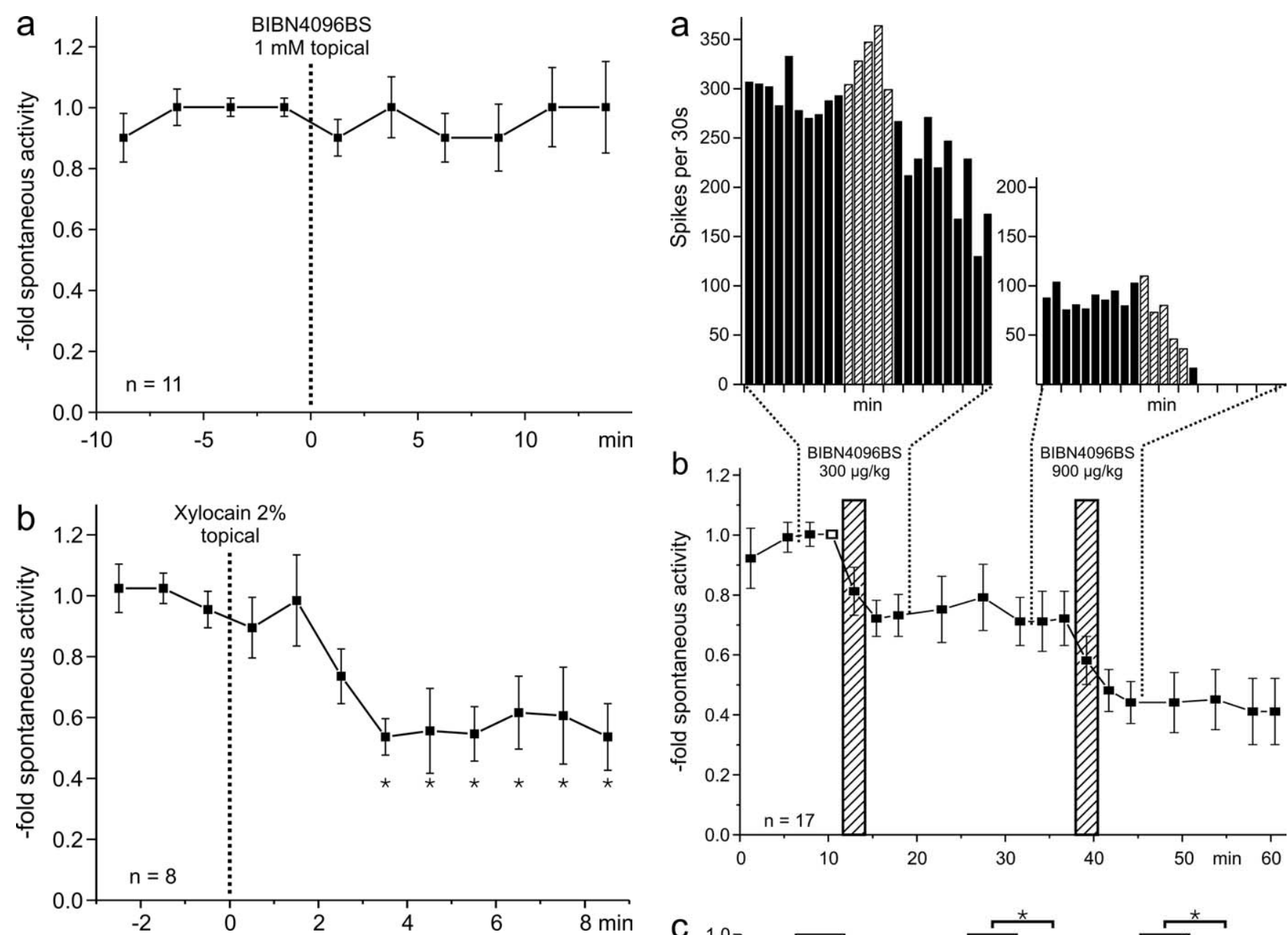

Figure 1. Activity of neurons with afferent input from the exposed cranial dura mater recorded in the spinal trigeminal nucleus caudalis. Activity was normalized to a period of $150 \mathrm{~s}$ before application of $1 \mathrm{~mm}$ BIBN4096BS (a) or $2 \%$ xylocaine $(\boldsymbol{b})$ at the dura. ${ }^{*} p<0.05$.

min period after the injection; $p<0.001 ; n=17$; Wilcoxon) (Fig. $2 c$ ). The activity did not recover to baseline levels during the following $20 \mathrm{~min}$. An additional dose of $900 \mu \mathrm{g} / \mathrm{kg}$ BIBN4096BS was then injected slowly. During the 5 min period after this injection, the discharge frequency was $36 \%$ lower than that during the 5 min period before the injection ( $p<0.001$; $n=17$; Wilcoxon). The cumulative doses of BIBN4096BS resulted in a 54\% reduction of the initial control activity $(p<0.001 ; n=17$; Wilcoxon) (Fig. $2 b$ ). Again, the activity did not recover within 20 min. In separate control experiments, injection of the vehicle (saline) at the same speed and volume did not change the frequency of spontaneous discharge ( $p=0.26 ; n=8$; Wilcoxon).

\section{Effects of thermal stimulation}

Increasing the local temperature of the dura mater in a ramp- or step-like mode caused an increase in neuronal activity (Fig. $3 a$ ). During the slow-temperature ramp $\left(32-44^{\circ} \mathrm{C}\right.$ within $\left.120 \mathrm{~s}\right)$, the discharge rate increased by $23 \%$ when compared with a control period of the same duration before the stimulation $(p=0.028$; $n=8$; $U$ test). Because of the small changes evoked by the slowheat ramp, a thermal activation threshold could not be reliably determined. The fast temperature steps caused pronounced phasic increases in activity. The phasic heat responses were analyzed by comparing the first $10 \mathrm{~s}$ after the temperature steps to 36,40 , and $44^{\circ} \mathrm{C}$, with the last $10 \mathrm{~s}$ at $32^{\circ} \mathrm{C}$. The activity after the three

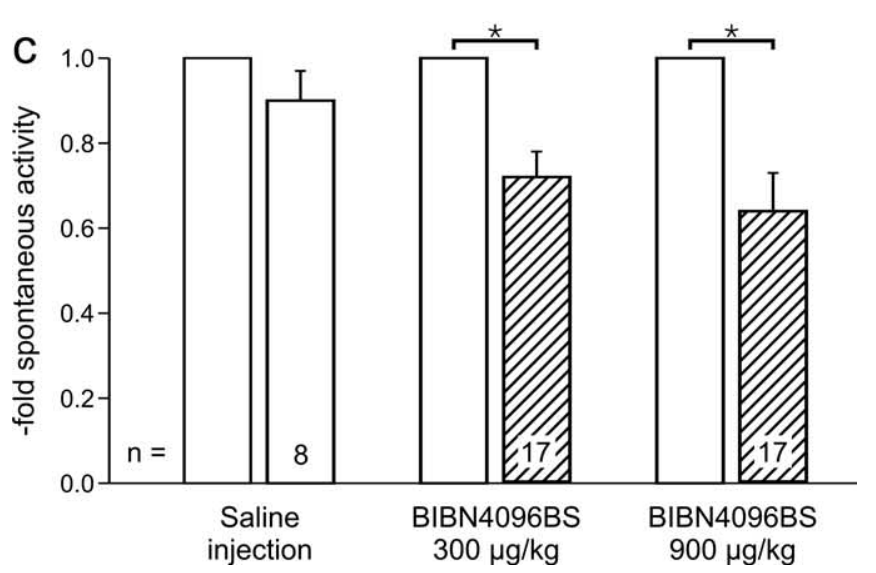

Figure 2. Effects of intravenous BIBN4096BS on the activity of spinal trigeminal nucleus neurons with dural afferent input. $\boldsymbol{a}$, Sample recording showing the spontaneous activity of one unit at $30 \mathrm{~s}$ intervals. Hatched bars indicate a period of BIBN4096BS injection. $\boldsymbol{b}$, Normalized activity of $17 \mathrm{U}$ on a real time scale. Each point represents the mean activity during intervals of $150 \mathrm{~s}$, normalized to the period of 150 s before the first drug application (open square). Hatched bars indicate injection of BIBN4096BS. Note the longer time between some 150 s intervals that were used for thermal testing. c, Average activity of units over subsequent periods of $5 \mathrm{~min}$ after injection of the indicated substance normalized to a period of 5 min before this injection. ${ }^{*} p<0.05$.

temperature steps taken together was increased by $171 \%$ ( $p=$ $0.001 ; n=13$; $U$ test) (Fig. $3 b$ ). Separate analysis of the three temperatures revealed significant increases in activity after all three temperature steps $(p=0.028,0.006$, and $0.003 ; n=13$ each; Wilcoxon tests) (Fig. $3 c$ ). Cooling of the dura did not change neuronal activity. Fast decreases in temperature did not 

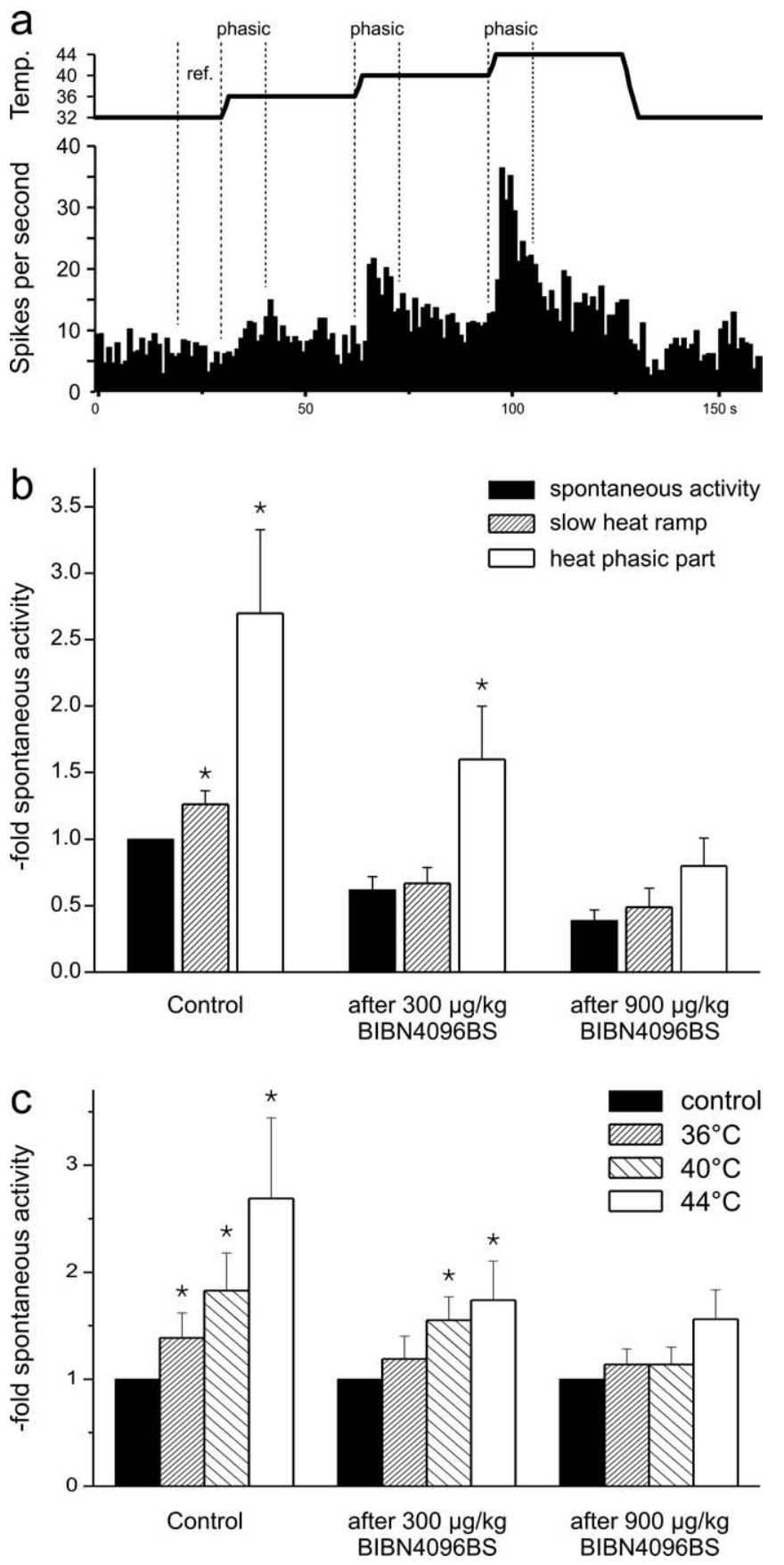

Figure 3. Heat-evoked activity of units with afferent input from the exposed cranial dura mater recorded in the spinal trigeminal nucleus caudalis and effects of BIBN4096BS. $\boldsymbol{a}$, Trigeminal neuron with phasic and tonic coding of dural heat stimulation. The activity is an average of four subsequent heat-step stimulation trials. The temperature (Temp.) of the dura was stepwise increased as indicated from 32 to $44^{\circ} \mathrm{C}$, with each step lasting for $30 \mathrm{~s}$. ref., Reference activity. $\boldsymbol{b}$, Neuronal activity of $13 \mathrm{U}$ normalized to the 150 s before the first heat stimulation. A slow-heat ramp from 32 to $44^{\circ} \mathrm{C}$ over a period of $120 \mathrm{~s}$ slightly increased the activity of spinal trigeminal neurons (hatched bars). Temperature steps caused a phasic increase in neuronal activity (heat phasic part: mean of first 10 s periods of temperature steps vs reference activity before the first heat stimulation as indicated in $\boldsymbol{a}$ by dotted lines). Responses to both thermal stimulation protocols were reduced after BIBN4096BS compared with the control period. $c$, Phasic increase in neuronal activity of $13 \mathrm{U}$ normalized to the reference activity before each heat stimulation (periods of $10 \mathrm{~s}$ indicated in $\boldsymbol{a}$ by dotted lines). After BIBN4096BS, no significant activation by heat stimuli was observed. ${ }^{*} p<0.05$ versus spontaneous activity $(\boldsymbol{b})$ or control $\operatorname{period}(\boldsymbol{c})$. cause any significant changes in neuronal activity (data not shown).

Effects of BIBN4096BS on activity evoked by thermal stimulation

After injection of BIBN4096BS, the responses to thermal stimulation were smaller compared with the respective stimuli before BIBN4096BS. In parallel with the decreased spontaneous activity, the responses to the slow-heat $\operatorname{ramp}(p=0.025, n=8$ after 300 $\mu \mathrm{g} / \mathrm{kg} ; p=0.012, n=8$ after $900 \mu \mathrm{g} / \mathrm{kg}$; Wilcoxon) as well as the phasic responses to the heat steps $(p=0.028, n=13$ after 300 $\mu \mathrm{g} / \mathrm{kg} ; p=0.004, n=13$ after $900 \mu \mathrm{g} / \mathrm{kg}$; Wilcoxon) were significantly smaller.

Subsequent to the first injection of BIBN4096BS, the neuronal activity during the slow-heat ramp was no longer different from the spontaneous activity; heat steps induced an increase in neuronal activity after $300 \mu \mathrm{g} / \mathrm{kg}$ BIBN4096BS ( $p=0.034 ; n=13$; Wilcoxon) but not after an additional injection of $900 \mu \mathrm{g} / \mathrm{kg}$. After the cumulative dose of $1200 \mu \mathrm{g} / \mathrm{kg}$ BIBN4096BS, heatevoked neuronal activity was no longer observed.

\section{Discussion}

BIBN4096BS has been developed as a nonpeptide CGRP receptor antagonist, the properties of which have been ascertained in a variety of preclinical in vitro and in vivo experiments (Edvinsson et al., 2002; Arulmani et al., 2004). Moreover, this compound had promising results in a clinical trial demonstrating that blockade of CGRP receptors offers a new therapeutical approach to the treatment of migraine attacks (Olesen et al., 2004).

A headache is assumed to be closely correlated with the activity of neurons in the spinal trigeminal nucleus, with afferent input from the cranial dura. Therefore, we developed an animal model to record neuronal activity in the STN as a measure of meningeal nociception.

An intravenous injection of BIBN4096BS had a profound and long-lasting inhibitory effect on the spontaneous activity of STN neurons. The activity evoked by heat ramps applied to the exposed dura mater was also significantly reduced after an intravenous injection of BIBN4096BS. In contrast, topical administration of BIBN4096BS did not significantly change the neuronal activity within the 15 min observation period.

\section{CGRP receptor location and possible sites of action}

The differential effect of BIBN4096BS on the activity in trigeminal neurons raises two questions: first, where is CGRP released and, second, where are CGRP receptors located? CGRP is expressed in a major proportion of trigeminal primary afferent neurons (O'Connor and van der Kooy, 1988). The cranial dura mater and intracerebral arteries of different species, including human, are densely innervated by CGRP-immunoreactive nerve fibers (Keller and Marfurt, 1991; Messlinger et al., 1993). In the trigeminal nucleus, CGRP-immunopositive terminals are abundant in the superficial laminas (Knyihar-Csillik et al., 1998). CGRP immunoreactivity is colocalized with capsaicin-sensitive neurons that express heat-transducing TRPV1 (transient receptor potential vanilloid subtype 1) receptors (Bae et al., 2004). In a variety of studies, the release of CGRP from meningeal tissues, including intracerebral arteries, has been measured and shown to be increased after noxious stimulation (Zagami et al., 1990; Messlinger et al., 1995). Central release of CGRP, which has been examined in the spinal dorsal horn (Schaible et al., 1994), is also likely to occur in the STN. Together, it is reasonable to hold that CGRP is released from both peripheral and central terminals of 
meningeal nociceptive afferents after noxious stimulation of the meninges.

CGRP receptors have been functionally located on intracranial arterial blood vessels, where they induce vasodilatation and increases in intracranial blood flow (Kurosawa et al., 1995; Brian et al., 1996; Williamson et al., 1997). CGRP receptors may also be located on primary afferents, because they have been demonstrated in cultured dorsal root ganglion cells using nanogoldlinked CGRP (Segond et al., 2002). Recent functional studies suggest that CGRP can modulate the sensitivity of nociceptive primary afferents in an isolated rat nerve-skin preparation (P. W. Reeh, personal communication). Thus, it is possible that CGRP released from meningeal afferents contributes to the control of afferent activity via autoreceptors. Local application of BIBN4096BS onto dural receptive fields did not change the activity of neurons in the spinal trigeminal neurons. Therefore, CGRP released from meningeal afferents is not likely to contribute to the spontaneous activity of central trigeminal neurons. This does not result from a lack of activity of these afferents, because topical application of local anesthetics lowered the spontaneous activity of the central neurons, indicating a tonic primary afferent input from the meninges. Because the neurons in our sample received convergent input from meningeal and facial areas, extracranial afferents also could have been targeted by intravenous administration of BIBN4096BS to bring about a reduction of the activity of central trigeminal neurons. In a similar preparation as that used in our experiments, the antimigraine drug sumatriptan was able to decrease the activation of spinal trigeminal neurons, particularly in response to facial stimulation (Burstein and Jakubowski, 2004).

In contrast to topical application, intravenous injection of BIBN4096BS was effective in lowering the activity of spinal trigeminal neurons. Consequently, we cannot exclude a central site of action of the CGRP receptor antagonist. This is supported by the observation that microiontophoretic injection of BIBN4096BS and $\mathrm{CGRP}_{8-37}$ at the recording site in the STN had an effect similar to that observed in our study with systemic administration (Storer et al., 2004). A central site of action of CGRP is further substantiated by the suppression of spontaneous activity in STN neurons after iontophoretic application of triptans (Storer and Goadsby, 1997). Triptans activate 5- $\mathrm{HT}_{1 \mathrm{~B} / \mathrm{D}}$ receptors, which are suggested to inhibit CGRP release both in peripheral meningeal tissues and in the STN (Goadsby and Edvinsson, 1994b). However, it should be noted that CGRP receptors, to date, have not been localized in the trigeminal nucleus, so the mechanisms of central CGRP effects remain unclear.

An argument against a central effect of BIBN4096BS is its limited ability to penetrate the blood-brain barrier (H. Doods, personal communication). However, it cannot be excluded that the blood-brain barrier is disrupted in the experimental situation (Kaube et al., 1993). Even a small percentage of the intravenously applied BIBN4096BS crossing the intact blood-brain barrier may be sufficient to produce the changes seen in our experiments.

\section{Doses of BIBN4096BS in comparison with other studies}

In a recent study (Storer et al., 2004), BIBN4096BS applied iontophoretically to the STN of cats caused a short-lasting inhibition of spontaneous and glutamate-evoked activity. In our study, BIBN4096BS (300 and $900 \mu \mathrm{g} / \mathrm{kg}$ ) reduced spontaneous activity for $\geq 20 \mathrm{~min}$. This difference may indicate that blockade of peripheral and central CGRP receptors is most effective in producing a long-lasting antinociceptive effect.
Species differences in the agonist affinity of CGRP receptors that are partly encoded by the receptor activity-modifying proteins 1-3 (Moreno et al., 2002) must also be taken into account to evaluate the reported differences in potency of BIBN4096BS. In pigs, increases in blood flow induced by TRPV1-mediated release of CGRP were dose-dependently inhibited by intravenous BIBN4096BS but not maximally at the highest dose $(1 \mathrm{mg} / \mathrm{kg})$ tested (Kapoor et al., 2003). In rats, no changes in heart rate, mean arterial pressure, systemic vascular conductance, or cardiac output were observed with BIBN4096BS at $3 \mathrm{mg} / \mathrm{kg}$ (Arulmani et al., 2004). Compared with rat CGRP receptors, human CGRP receptors have $>100$-fold the affinity for BIBN4096BS (Mallee et al., 2002). In the first clinical trial published by Olesen et al. (2004), the maximum response rate after $2 \mathrm{~h}$ of drug administration occurred at a dose of $\sim 70 \mu \mathrm{g} / \mathrm{kg}$. Taking into account the mentioned differences in affinity between species, the cumulative dose of $1.2 \mathrm{mg} / \mathrm{kg}$ used in our experiments is not considered to be an unreasonably high dose for rats.

\section{Responses to thermal stimulation}

Heat sensitivity of primary afferents in the exposed dura has been assessed with a focused light beam recording from the guinea pig nasociliary nerve (Bove and Moskowitz, 1997). In another study, noxious cold stimuli were applied onto the rat dura to activate neurons in the STN with afferent meningeal input (Ebersberger et al., 1999). In pilot experiments before our examination, we tested various heat and cold stimulation protocols on the exposed dura. Longer periods of fixed temperatures $\left(36,40\right.$, and $\left.44^{\circ} \mathrm{C}\right)$ did not cause reliable changes in neuronal activity. In contrast, faster temperature changes that could only be applied with the newly developed vortex device (see Materials and Methods) produced phasic temperature-dependent increases with rapid adaptation of neuronal activity. These heat-evoked responses were reduced by intravenous injection of BIBN4096BS at a rate similar to the decrease in spontaneous activity and thus turned out to be a reliable measure of stimulus-dependent neuronal activity.

The present experiments also show that STN neurons code dural heating over a range of $32-44^{\circ} \mathrm{C}$. Although the dura is unlikely to experience such a temperature range, peripheral and central sensitization might shift the working range of primary afferents and second-order neurons down to body temperature, as has been shown in cutaneous afferents (Petho et al., 2001). Sensitization of primary meningeal afferents by endogenous mediators such as nitric oxide, inflammatory mediators, and low $\mathrm{pH}$ has been demonstrated previously (Strassman et al., 1996; Burstein et al., 1998; Levy and Strassman, 2004).

\section{Possible clinical significance of CGRP receptor blockade}

Triptans, $5-\mathrm{HT}_{1 \mathrm{~B} / \mathrm{D}}$ receptor agonists, are currently some of the most commonly used substances for the treatment of migraines. In addition to their direct vasoconstrictory effect, the inhibition of CGRP release from primary afferent endings is regarded to be most important. However, among the patients treated with triptans, nearly $40 \%$ are nonresponders, $30 \%$ of the responders sustain recurrent headaches within $2-24 \mathrm{~h}$, and $70 \%$ of patients do not become free of pain (Ferrari et al., 2002). Therefore, a new, possibly additional, target site for drug therapy seems desirable. CGRP receptors have been proposed as a new therapeutical approach, and recently, these ideas were confirmed in a randomized, multicenter, double-blind study in acute migraine patients (Olesen et al., 2004).

In our model of headache pathophysiology, BIBN4096BS reduced spontaneous and thermally evoked activity in STN neu- 
rons. These experimental data strengthen the notion that peripheral or central inhibition of CGRP receptors may be useful in the treatment of migraine pain and other headaches.

\section{References}

Arulmani U, Schuijt MP, Heiligers JP, Willems EW, Villalon CM, Saxena PR (2004) Effects of the calcitonin gene-related peptide (CGRP) receptor antagonist BIBN4096BS on alpha-CGRP-induced regional haemodynamic changes in anaesthetised rats. Basic Clin Pharmacol Toxicol 94:291-297.

Ashina M, Bendtsen L, Jensen R, Schifter S, Jansen-Olesen I, Olesen J (2000) Plasma levels of calcitonin gene-related peptide in chronic tension-type headache. Neurology 55:1335-1340.

Bae YC, Oh JM, Hwang SJ, Shigenaga Y, Valtschanoff JG (2004) Expression of vanilloid receptor TRPV1 in the rat trigeminal sensory nuclei. J Comp Neurol 478:62-71.

Beise RD, Carstens E, Kohlloffel LU (1998) Psychophysical study of stinging pain evoked by brief freezing of superficial skin and ensuing short-lasting changes in sensations of cool and cold pain. Pain 74:275-286.

Bennett AD, Chastain KM, Hulsebosch CE (2000) Alleviation of mechanical and thermal allodynia by CGRP8-37 in a rodent model of chronic central pain. Pain 86:163-175.

Bove GM, Moskowitz MA (1997) Primary afferent neurons innervating guinea pig dura. J Neurophysiol 77:299-308.

Brain SD, Williams TJ (1985) Inflammatory oedema induced by synergism between calcitonin gene-related peptide (CGRP) and mediators of increased vascular permeability. Br J Pharmacol 86:855-860.

Brain SD, Williams TJ, Tippins JR, Morris HR, MacIntyre I (1985) Calcitonin gene-related peptide is a potent vasodilator. Nature 313:54-56.

Brian JE, Faraci FM, Heistad DD (1996) Recent insights into the regulation of cerebral circulation. Clin Exp Pharmacol Physiol 23:449-457.

Burstein R, Jakubowski M (2004) Analgesic triptan action in an animal model of intracranial pain: a race against the development of central sensitization. Ann Neurol 55:27-36.

Burstein R, Yamamura H, Malick A, Strassman AM (1998) Chemical stimulation of the intracranial dura induces enhanced responses to facial stimulation in brain stem trigeminal neurons. J Neurophysiol 79:964-982.

Caterina MJ, Rosen TA, Tominaga M, Brake AJ, Julius D (1999) A capsaicin-receptor homologue with a high threshold for noxious heat. Nature 398:436-441.

Caterina MJ, Leffler A, Malmberg AB, Martin WJ, Trafton J, Petersen-Zeitz KR, Koltzenburg M, Basbaum AI, Julius D (2000) Impaired nociception and pain sensation in mice lacking the capsaicin receptor. Science 288:306-313.

Davis JB, Gray J, Gunthorpe MJ, Hatcher JP, Davey PT, Overend P, Harries MH, Latcham J, Clapham C, Atkinson K, Hughes SA, Rance K, Grau E, Harper AJ, Pugh PL, Rogers DC, Bingham S, Randall A, Sheardown SA (2000) Vanilloid receptor-1 is essential for inflammatory thermal hyperalgesia. Nature 405:183-187.

Dodick D, Lipton RB, Martin V, Papademetriou V, Rosamond W, Maassenvandenbrink A, Loutfi H, Welch KM, Goadsby PJ, Hahn S, Hutchinson S, Matchar D, Silberstein S, Smith TR, Purdy RA, Saiers J (2004) Consensus statement: cardiovascular safety profile of triptans (5-HT agonists) in the acute treatment of migraine. Headache 44:414-425.

Doods H, Hallermayer G, Wu D, Entzeroth M, Rudolf K, Engel W, Eberlein W (2000) Pharmacological profile of BIBN4096BS, the first selective small molecule CGRP antagonist. Br J Pharmacol 129:420-423.

Ebersberger A, Averbeck B, Messlinger K, Reeh PW (1999) Release of substance $\mathrm{P}$, calcitonin gene-related peptide and prostaglandin $\mathrm{E} 2$ from rat dura mater encephali following electrical and chemical stimulation in vitro. Neuroscience 89:901-907.

Edvinsson L, Ekman R, Jansen I, McCulloch J, Uddman R (1987) Calcitonin gene-related peptide and cerebral blood vessels: distribution and vasomotor effects. J Cereb Blood Flow Metab 7:720-728.

Edvinsson L, Alm R, Shaw D, Rutledge RZ, Koblan KS, Longmore J, Kane SA (2002) Effect of the CGRP receptor antagonist BIBN4096BS in human cerebral, coronary and omental arteries and in SK-N-MC cells. Eur J Pharmacol 434:49-53.

Ferrari MD, Goadsby PJ, Roon KI, Lipton RB (2002) Triptans (serotonin, $5-\mathrm{HT}_{1 \mathrm{~B} / 1 \mathrm{D}}$ agonists) in migraine: detailed results and methods of a metaanalysis of 53 trials. Cephalalgia 22:633-658.

Forster C, Handwerker HO (1990) Automatic classification and analysis of microneurographic spike data using a PC/AT. J Neurosci Methods 31:109-118.

Gamse R, Saria A (1986) Nociceptive behavior after intrathecal injections of substance $\mathrm{P}$, neurokinin A and calcitonin gene-related peptide in mice. Neurosci Lett 70:143-147.

Goadsby PJ, Edvinsson L (1993) The trigeminovascular system and migraine: studies characterizing cerebrovascular and neuropeptide changes seen in humans and cats. Ann Neurol 33:48-56.

Goadsby PJ, Edvinsson L (1994a) Human in vivo evidence for trigeminovascular activation in cluster headache. Neuropeptide changes and effects of acute attacks therapies. Brain 117:427-434.

Goadsby PJ, Edvinsson L (1994b) Joint 1994 Wolff award presentation. Peripheral and central trigeminovascular activation in cat is blocked by the serotonin (5HT)-1D receptor agonist 311C90. Headache 34:394-399.

Goadsby PJ, Edvinsson L, Ekman R (1990) Vasoactive peptide release in the extracerebral circulation of humans during migraine headache. Ann Neurol 28:183-187.

Hargreaves RJ, Shepheard SL (1999) Pathophysiology of migraine-new insights. Can J Neurol Sci 26:S12-S19.

Jenkins DW, Langmead CJ, Parsons AA, Strijbos PJ (2004) Regulation of calcitonin gene-related peptide release from rat trigeminal nucleus caudalis slices in vitro. Neurosci Lett 366:241-244.

Kapoor K, Arulmani U, Heiligers JPC, Garrelds IM, Willems EW, Doods H, Villalon CM, Saxena PR (2003) Effects of the CGRP receptor antagonist BIBN4096BS on capsaicin-induced carotid haemodynamic changes in anaesthetised pigs. Br J Pharmacol 140:329-338.

Kaube H, Hoskin KL, Goadsby PJ (1993) Inhibition by sumatriptan of central trigeminal neurones only after blood-brain barrier disruption. Br J Pharmacol 109:788-792.

Keller JT, Marfurt CF (1991) Peptidergic and serotoninergic innervation of the rat dura mater. J Comp Neurol 309:515-534.

Knyihar-Csillik E, Tajti J, Samsam M, Sary G, Buzas P, Vecsei L (1998) Depletion of calcitonin gene-related peptide from the caudal trigeminal nucleus of the rat after electrical stimulation of the Gasserian ganglion. Exp Brain Res 118:111-114.

Koulchitsky S, Fischer MJM, De Col R, Schlechtweg PM, Messlinger K (2004) Biphasic response to nitric oxide of spinal trigeminal neurons with meningeal input in rat-possible implications for the pathophysiology of headaches. J Neurophysiol 92:1320-1328.

Kurosawa M, Messlinger K, Pawlak M, Schmidt RF (1995) Increase of meningeal blood flow after electrical stimulation of rat dura mater encephali: mediation by calcitonin gene-related peptide. $\mathrm{Br} \mathrm{J}$ Pharmacol 114:1397-1402.

Lassen LH, Haderslev PA, Jacobsen VB, Iversen HK, Sperling B, Olesen J (2002) CGRP may play a causative role in migraine. Cephalalgia 22:54-61.

Levy D, Strassman AM (2004) Modulation of dural nociceptor mechanosensitivity by the nitric oxide-cyclic GMP signaling cascade. J Neurophysiol 92:766-772.

Mallee JJ, Salvatore CA, LeBourdelles B, Oliver KR, Longmore J, Koblan KS, Kane SA (2002) Receptor activity-modifying protein 1 determines the species selectivity of non-peptide CGRP receptor antagonists. J Biol Chem 277:14294-14298.

Messlinger K, Hanesch U, Baumgartel M, Trost B, Schmidt RF (1993) Innervation of the dura mater encephali of cat and rat: ultrastructure and calcitonin gene-related peptide-like and substance P-like immunoreactivity. Anat Embryol (Berl) 188:219-237.

Messlinger K, Hanesch U, Kurosawa M, Pawlak M, Schmidt RF (1995) Calcitonin gene related peptide released from dural nerve fibers mediates increase of meningeal blood flow in the rat. Can J Physiol Pharmacol 73:1020-1024.

Moreno MJ, Abounader R, Hebert E, Doods H, Hamel E (2002) Efficacy of the non-peptide CGRP receptor antagonist BIBN4096BS in blocking CGRPinduced dilations in human and bovine cerebral arteries: potential implications in acute migraine treatment. Neuropharmacology 42:568-576.

O'Connor TP, van der Kooy D (1988) Enrichment of a vasoactive neuropeptide (calcitonin gene related peptide) in the trigeminal sensory projection to the intracranial arteries. J Neurosci 8:2468-2476.

Olesen J, Diener HC, Husstedt IW, Goadsby PJ, Hall D, Meier U, Pollentier S, Lesko LM (2004) Calcitonin gene-related peptide receptor antagonist 
BIBN 4096 BS for the acute treatment of migraine. N Engl J Med 350:1104-1110

Petho G, Derow A, Reeh PW (2001) Bradykinin-induced nociceptor sensitization to heat is mediated by cyclooxygenase products in isolated rat skin. Eur J Neurosci 14:210-218.

Schaible HG, Freudenberger U, Neugebauer V, Stiller RU (1994) Intraspinal release of immunoreactive calcitonin gene-related peptide during development of inflammation in the joint in vivo-a study with antibody microprobes in cat and rat. Neuroscience 62:1293-1305.

Schepelmann K, Ebersberger A, Pawlak M, Oppmann M, Messlinger K (1999) Response properties of trigeminal brain stem neurons with input from dura mater encephali in the rat. Neuroscience 90:543-554.

Segond VB, Pastor A, Biskup C, Schlegel C, Benndorf K, Schaible HG (2002) Localization of functional calcitonin gene-related peptide binding sites in a subpopulation of cultured dorsal root ganglion neurons. Neuroscience 110:131-145.

Storer RJ, Goadsby PJ (1997) Microiontophoretic application of serotonin (5HT) $1 \mathrm{~B} / 1 \mathrm{D}$ agonists inhibits trigeminal cell firing in the cat. Brain 120:2171-2177.
Storer RJ, Akerman S, Goadsby PJ (2004) Calcitonin gene-related peptide (CGRP) modulates nociceptive trigeminovascular transmission in the cat. Br J Pharmacol 142:1171-1181.

Strassman AM, Raymond SA, Burstein R (1996) Sensitization of meningeal sensory neurons and the origin of headaches. Nature 384:560-564.

Sun RQ, Lawand NB, Willis WD (2003) The role of calcitonin gene-related peptide (CGRP) in the generation and maintenance of mechanical allodynia and hyperalgesia in rats after intradermal injection of capsaicin. Pain 104:201-208.

Williamson DJ, Hargreaves RJ, Hill RG, Shepheard SL (1997) Intravital microscope studies on the effects of neurokinin agonists and calcitonin gene-related peptide on dural vessel diameter in the anaesthetized rat. Cephalalgia 17:518-524.

Zagami AS, Goadsby PJ, Edvinsson L (1990) Stimulation of the superior sagittal sinus in the cat causes release of vasoactive peptides. Neuropeptides 16:69-75.

Zimmermann M (1983) Ethical guidelines for investigations of experimental pain in conscious animals. Pain 16:109-110. 